\title{
Insulin and IGF1 receptors in human cardiac microvascular endothelial cells: metabolic, mitogenic and anti-inflammatory effects
}

\author{
Karolina Bäck, Rakibul Islam, Git S Johansson, Simona I Chisalita and Hans J Arnqvist \\ Division of Cell Biology, Department of Clinical and Experimental Medicine, Faculty of Health Sciences, Linköping University, S-581 85 Linköping, Sweden \\ (Correspondence should be addressed to H J Arnqvist; Email: hans.arnqvist@liu.se)
}

\begin{abstract}
Diabetes is associated with microcirculatory dysfunction and heart failure and changes in insulin and IGF1 levels. Whether human cardiac microvascular endothelial cells (HMVEC-Cs) are sensitive to insulin and/or IGF1 is not known. We studied the role of insulin receptors (IRs) and IGF1 receptors (IGF1Rs) in metabolic, mitogenic and antiinflammatory responses to insulin and IGF1 in HMVEC-Cs and human umbilical vein endothelial cells (HUVECs). IR and IGF1R gene expression was studied using real-time RT-PCR. Receptor protein expression and phosphorylation were determined by western blot and ELISA. Metabolic and mitogenic effects were measured as glucose accumulation and thymidine incorporation. An E-selectin ELISA was used to investigate inflammatory responses. According to gene expression and protein in HMVEC-Cs and HUVECs, IGF1R is more abundant than IR. Immunoprecipitation
\end{abstract}

with anti-IGF1R antibody and immunoblotting with anti-IR antibody and vice versa, showed insulin/IGF1 hybrid receptors in HMVEC-Cs. IGF1 at a concentration of $10^{-8} \mathrm{~mol} / 1$ significantly stimulated phosphorylation of both IGF1R and IR in HMVEC-Cs. In HUVECs IGF1 $10^{-8} \mathrm{~mol} / \mathrm{l}$ phosphorylated IGF1R. IGF1 stimulated DNA synthesis at $10^{-8} \mathrm{~mol} / \mathrm{l}$ and glucose accumulation at $10^{-7} \mathrm{~mol} / \mathrm{l}$ in HMVEC-Cs. TNF- $\alpha$ dramatically increased E-selectin expression, but no inflammatory or antiinflammatory effects of insulin, IGF1 or high glucose were seen. We conclude that HMVEC-Cs express more IGF1Rs than IRs, and mainly react to IGF1 due to the predominance of IGF1Rs and insulin/IGF1 hybrid receptors. TNF- $\alpha$ has a pronounced pro-inflammatory effect in HMVEC-Cs, which is not counteracted by insulin or IGF1.

Journal of Endocrinology (2012) 215, 89-96

\section{Introduction}

The effects of diabetes on the microcirculation manifest as diabetic microangiopathy and on the macrocirculation as atherosclerosis and media sclerosis. The development of these complications is dependent on the integrity and function of the endothelium (Kim et al. 2006, Pambianco et al. 2006). There is a strong association between microvascular complications and cardiomyopathy leading to heart failure (Tarquini et al. 2010). Alterations in the insulinlike growth factor (IGF) system have been demonstrated in diabetic patients when compared with healthy individuals (Bereket et al. 1999, Delafontaine et al. 2004, Hedman et al. 2004).

Diabetes and insulin resistance are associated with inflammation. It has been suggested that the high levels of TNF- $\alpha$ expressed during inflammation is a link between insulin resistance and coronary microvascular dysfunction, as TNF- $\alpha$ has been shown to affect superoxide production and NO bioactivity (Picchi et al. 2010). Furthermore, insulin has been shown to have anti-inflammatory effects, suppressing

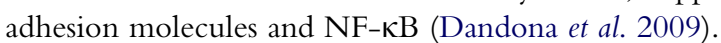

Insulin and IGF1 mediate their effects by binding to their cognate cell surface receptors: the insulin receptor (IR) and the IGF1 receptor (IGF1R). The receptors are highly homologous and originate from the same family of tyrosine kinase receptors (Siddle et al. 2001). They both consist of two $\alpha \beta$-dimers where the $\alpha$-subunit is the ligand-binding extracellular part and the $\beta$-subunit, containing the tyrosine kinase domain, is the transmembrane part (Siddle et al. 2001). Insulin and IGF1 cross-react with each other's receptor but with 100- to 1000-fold lower affinity than to their own receptor (Werner et al. 2008).

Stoichiometric assembly of the IR and IGF1R $\alpha \beta$-dimers results in the formation of an insulin/IGF1 hybrid receptor with one $\alpha \beta$-dimer from each original receptor (Moxham et al. 1989). Hybrid receptors have been shown to have a binding affinity similar to that of the IGF1R, i.e. they bind IGF1 with high affinity, but not insulin (Soos et al. 1993, Slaaby et al. 2006). We have reported that IRs and IGF1Rs form insulin/ IGF1 hybrid receptors in human macro- and microvascular endothelial cells (Nitert et al. 2005, Chisalita et al. 2006, Johansson et al. 2008), which could be of importance for insulin sensitivity. 
Endothelial cells from different locations show a range of heterogeneity with respect to appearance, phenotype, protein expression and intracellular enzymes (Cines et al. 1998). In human diabetic myocardium, endothelial swelling and thickening of the capillary basement membrane occur (Asghar et al. 2009). Human microvascular endothelial cells (HMVECs) are sensitive to IGF1s but insensitive to insulin, and IGF1Rs are several times more abundant on these cells than IRs (Chisalita \& Arnqvist 2004). Whether human microvascular endothelial cells-cardiac (HMVEC-Cs) are sensitive to insulin and/or IGF1 is not known. Our aim was therefore to study the role of IRs and IGF1Rs in metabolic, mitogenic and anti-inflammatory responses to insulin and IGF1 in HMVEC-Cs. For comparison, human umbilical vein endothelial cells (HUVECs) were also investigated.

\section{Materials and Methods}

\section{Cells and culture}

Cell culture flasks and plates were purchased from Corning (Schiphol-Rijk, The Netherlands) and all other cell culture materials were purchased from Invitrogen or as indicated in the text.

\section{Human cardiac microvascular endothelial cells}

Primary cultures of HMVEC-Cs from different batches were purchased from Lonza (Basel, Switzerland). The cells stained positive for acetylated LDL and von Willebrand's (Factor VIII) antigen but did not stain for smooth muscle $\boldsymbol{\alpha}$-actin. They were cultured in EGM-2MV (Microvascular endothelial growth medium-2) (Lonza) in $75 \mathrm{~cm}^{2}$ culture flasks until near confluent. Medium was changed two to three times a week and cells were passaged using trypsin (Lonza) when near confluent. Cells used in experiments were from passages three to nine.

\section{Human umbilical vein endothelial cells}

HUVECs were isolated from umbilical cords provided by the Department of Obstetrics, Linköping University Hospital, Linköping, Sweden. The umbilical cords were collected in sterile PBS containing penicillin $(100 \mathrm{IU} / \mathrm{ml})$ and streptomycin $(100 \mu \mathrm{g} / \mathrm{ml})$ at $4{ }^{\circ} \mathrm{C}$. The umbilical cord vein was washed with PBS and then incubated with $0.5 \mathrm{mg} / \mathrm{ml}$ collagenase type 1 (Sigma-Aldrich) in DMEM containing $25 \mathrm{mmol} / 1 \mathrm{HEPES}$, $10 \mathrm{IU} / \mathrm{ml}$ penicillin and $10 \mu \mathrm{g} / \mathrm{ml}$ streptomycin for $15 \mathrm{~min}$ at $37^{\circ} \mathrm{C}$. The collagenase solution containing the endothelial cells was collected in DMEM containing $10 \mathrm{IU} / \mathrm{ml}$ penicillin and $10 \mu \mathrm{g} / \mathrm{ml}$ streptomycin, and the vein was then washed with PBS to collect any remaining cells. The cell suspension was centrifuged twice at $500 \mathrm{~g}$ for $5 \mathrm{~min}$ and washed in between with HUVEC culture medium (DMEM supplemented with $8 \%(\mathrm{v} / \mathrm{v})$ foetal bovine serum,
$100 \mathrm{IU} / \mathrm{ml}$ penicillin, $100 \mu \mathrm{g} / \mathrm{ml}$ streptomycin, $2 \mu \mathrm{g} / \mathrm{ml}$ Fungizone and EGM-2 SingleQuot kit (Lonza) $(0 \cdot 04 \%$ $(\mathrm{v} / \mathrm{v})$ hydrocortisone, $0 \cdot 4 \%(\mathrm{v} / \mathrm{v})$ human fibroblast growth factor, $0 \cdot 1 \%(\mathrm{v} / \mathrm{v})$ vascular endothelial growth factor, $0 \cdot 1 \%(\mathrm{v} / \mathrm{v}) \mathrm{R}^{3}-\mathrm{IGF} 1,0 \cdot 1 \%(\mathrm{v} / \mathrm{v})$ ascorbic acid, $0 \cdot 1 \%(\mathrm{v} / \mathrm{v})$ human epithelial growth factor, $0 \cdot 1 \%(\mathrm{v} / \mathrm{v})$ gentamycinamphotericin). The cells were cultured in $75 \mathrm{~cm}^{2}$ flasks coated with $0 \cdot 2 \%(\mathrm{w} / \mathrm{v})$ gelatin in HUVEC culture medium. The medium was changed two to three times a week and cells were passaged using trypsin when near confluent. Cells used in experiments were from passages one to three.

\section{Real-time RT-PCR}

RNA was extracted using E.Z.N.A. Total RNA kit (Omega Bio-tek, Doraville, GA, USA) according to the manufacturer's instructions. Cells were lysed directly in the flasks and RNA samples were stored at $-70{ }^{\circ} \mathrm{C}$ until further use. One microgram of RNA was transcribed to cDNA using SuperScript II Reverse Transcriptase, purchased from Invitrogen. cDNA was stored at $-20{ }^{\circ} \mathrm{C}$ until further use.

Comparative quantitative real-time PCR was performed using primers and probes for IR, IGF1R and GLUT4, purchased from Scandinavian Gene Synthesis (Köping, Sweden; Bäck \& Arnqvist 2009). Twenty to one hundred nanogram cDNA was mixed with $300 \mathrm{nmol} / 1$ sense and antisense primers, $50 \mathrm{nmol} / \mathrm{l}$ probe, $12.5 \mu \mathrm{l} 2 \times$ TaqMan Fast Universal PCR Master Mix (Applied Biosystems) and water to a final volume of $25 \mu \mathrm{l}$. DNA amplification was run and measured in an ABI Prism 7500 Fast Sequence Detector System (Applied Biosystems). Data were analysed using the $\Delta C_{\mathrm{t}}$ method described by Applied Biosystems Bulletin \#2. Pre-developed TaqMan assay reagent GAPDH, purchased from Applied Biosystems, was used for normalisation.

\section{Receptor ELISA}

Near confluent HMVEC-Cs or HUVECs were serumdeprived overnight in low glucose $(5.6 \mathrm{mmol} / \mathrm{l})$ DMEM containing $0 \cdot 1 \%$ glucose, $100 \mathrm{IU} / \mathrm{ml}$ penicillin, $100 \mu \mathrm{g} / \mathrm{ml}$ streptomycin, $2 \mu \mathrm{g} / \mathrm{ml}$ Fungizone and $0 \cdot 1 \%$ $(\mathrm{w} / \mathrm{v})$ BSA. Insulin or IGF1 at indicated concentrations were added to the flasks and they were incubated at $37^{\circ} \mathrm{C}$ for $10 \mathrm{~min}$. The cells were then washed twice with cold PBS and collected in cold PBS. The suspension was centrifuged at $700 \mathrm{~g}$ and $4{ }^{\circ} \mathrm{C}$ for $5 \mathrm{~min}$. The pellet was dissolved in lysis buffer (pH 7.5) containing $20 \mathrm{mmol} / \mathrm{l}$ TrizmaBase, $150 \mathrm{mmol} / 1 \mathrm{NaCl}, 5 \mathrm{mmol} / 1 \mathrm{EDTA}, 0 \cdot 5 \%$ (w/v) sodium deoxycholate and $0.5 \%(\mathrm{v} / \mathrm{v})$ Triton X-100 with the addition of $1 \mathrm{mmol} / \mathrm{l}$ phenylmethylsulphonyl fluoride (PMSF), $1.5 \mu \mathrm{g} / \mathrm{ml}$ leupeptin, $1 \mathrm{mmol} / 1 \mathrm{Na}_{3} \mathrm{VO}_{4}$ and $1.5 \mu \mathrm{g} / \mathrm{ml}$ aprotinin before use. The cells were lysed on ice for $30 \mathrm{~min}$ and then centrifuged at $12000 \mathrm{~g}$ and $4{ }^{\circ} \mathrm{C}$ for $10 \mathrm{~min}$. The supernatant was stored at $-70{ }^{\circ} \mathrm{C}$ until further use. Human total IR, total IGF1R, phospho-IR or phospho-IGF1R were measured using DuoSet IC kits from R\&D Systems 
(Minneapolis, MN, USA) and analyses were performed according to the manufacturer's instructions. Total protein was measured using BCA Protein Assay Kit (Pierce, Rockford, IL, USA) according to the manufacturer's instructions.

\section{Immunoprecipitation, SDS-PAGE and western blot}

HMVEC-Cs were serum-deprived overnight in DMEM containing $100 \mathrm{IU} / \mathrm{ml}$ penicillin, $100 \mu \mathrm{g} / \mathrm{ml}$ streptomycin, $2 \mu \mathrm{g} / \mathrm{ml}$ Fungizone and $0 \cdot 1 \%(\mathrm{w} / \mathrm{v})$ BSA. Insulin or IGF1 at indicated concentrations were added to the flasks and incubated at $37^{\circ} \mathrm{C}$ for $10 \mathrm{~min}$. The medium was then removed and lysis buffer ( $\mathrm{pH} 7 \cdot 5$ ) containing $20 \mathrm{mmol} / 1$ TrizmaBase, $150 \mathrm{mmol} / 1 \mathrm{NaCl}, 5 \mathrm{mmol} / 1 \mathrm{EDTA}, 0 \cdot 5 \%$ (w/v) sodium deoxycholate and $0.5 \%(\mathrm{v} / \mathrm{v})$ Triton X-100 with addition of $1 \mathrm{mmol} / 1$ PMSF, $1.5 \mu \mathrm{g} / \mathrm{ml}$ leupeptin, $1 \mathrm{mmol} / 1 \mathrm{Na}_{3} \mathrm{VO}_{4}$ and $1.5 \mu \mathrm{g} / \mathrm{ml}$ aprotinin was added to the flasks. The cells were lysed on ice for $30 \mathrm{~min}$ and then harvested by scraping. The lysate was centrifuged at $12000 \mathrm{~g}$ for $15 \mathrm{~min}$ at $4{ }^{\circ} \mathrm{C}$ and the supernatant was stored at $-70{ }^{\circ} \mathrm{C}$ until further use.

HMVEC-C lysates were immunoprecipitated (IP) with either rabbit polyclonal anti-IR $\beta$ antibody (c-19) or rabbit polyclonal anti-IGF1R $\beta$ antibody (c-20) (Santa Cruz Biotechnology), diluted $1: 400$ and incubated at $4{ }^{\circ} \mathrm{C}$ for $2 \mathrm{~h}$. Twenty milligrams per milliliter Protein A Sepharose (GE Healthcare Bio-Sciences AB, Uppsala, Sweden) in $0 \cdot 1 \%(\mathrm{w} / \mathrm{v})$ BSA was then added and the lysates were incubated overnight at $4{ }^{\circ} \mathrm{C}$ with gentle rocking. The next day lysates were centrifuged at $6500 \boldsymbol{g}$ for $5 \mathrm{~min}$, supernatants were removed and pellets were washed three times with the lysis buffer. Pellets were then dissolved in SDS-PAGE sample buffer $(6 \cdot 25 \mathrm{mmol} / 1$ TrizmaBase, $1 \%(\mathrm{w} / \mathrm{v})$ SDS, $10 \%$ (v/v) glycerol, $0 \cdot 001 \%(\mathrm{v} / \mathrm{v})$ bromophenol) with addition of $2 \%(\mathrm{v} / \mathrm{v}) \beta$-mercaptoethanol and boiled for $3 \mathrm{~min}$.

IP proteins were separated in $7 \cdot 5 \%$ acrylamide gels and then electrophoretically blotted to polyvinylidene difluoride membranes. After blocking in 3\% (w/v) BSA, membranes were incubated with antiphosphotyrosine (PY20) or, after stripping membranes in $62 \mathrm{mmol} / \mathrm{l}$ Tris $-\mathrm{HCl}, 2 \%$ (w/v) sodium dodecylsulphate, and $100 \mathrm{mmol} / 1 \beta$-mercaptoethanol for $30 \mathrm{~min}$ at $56^{\circ} \mathrm{C}$, with anti-IGF1R (c-20) or anti-IR (c-19) antibodies. Bound antibodies were detected using HRP-conjugated secondary antibodies and the ECL-plus kit from GE Healthcare.

\section{Thymdine incorporation}

HMVEC-Cs, around 100000 cells/well, were plated in sixwell plates and grown until near confluence. The cells were incubated with insulin or IGF1 at indicated concentrations in serum-free, low glucose DMEM overnight and then with $1 \mu \mathrm{Ci} / \mathrm{ml}\left[6-{ }^{3} \mathrm{H}\right]$ thymidine for $3 \mathrm{~h}$ at $37^{\circ} \mathrm{C}, 5 \% \mathrm{CO}_{2}$. Cells were washed and DNA was then precipitated in ice cold $5 \%(\mathrm{w} / \mathrm{v})$ trichloroacetic acid for $15 \mathrm{~min}$ at $4{ }^{\circ} \mathrm{C}$. After treatment with $0.1 \mathrm{~mol} / 1$ potassium hydroxide for $1-2 \mathrm{~h}$ at room temperature, the lysate was added to UltimaGold scintillation fluid (Chemical Instruments $A B$ (CiAB), Sollentuna, Sweden) and the radioactivity was measured. Data were expressed as percent of radioactivity in untreated control cells. VEGF-165 (R\&D Systems) was used as a positive control.

\section{Glucose accumulation}

HMVEC-Cs, around 100000 cells/well, were plated in six-well plates and grown until near confluence. The cells were serum-deprived overnight and then incubated for $3 \mathrm{~h}$ in serum-free, low glucose DMEM with addition of $0 \cdot 2 \mu \mathrm{Ci} / \mathrm{ml} \mathrm{D}-\left[\mathrm{U}_{-}{ }^{14} \mathrm{C}\right]$ glucose and insulin or IGF1 at indicated concentrations. The wells were then washed and cells were lysed in $0 \cdot 1 \%(\mathrm{w} / \mathrm{v})$ sodium dodecylsulphate. The lysate was added to UltimaGold scintillation fluid (CiAB) and the radioactivity was measured. Data were expressed as percent of radioactivity in unstimulated control cells. VEGF-165 (R\&D Systems) was used as a positive control.

\section{E-selectin ELISA}

Expression of E-selectin was detected using an ELISA as described by Strindhall et al. (1997). Briefly, HUVECs or HMVEC-Cs, 10000 cells/well, were seeded in a 96-well microplate and incubated for 2 days. They were then stimulated for $4 \mathrm{~h}$ with glucose, TNF- $\alpha$, IL6, IGF1 or insulin at indicated concentrations. The cells were fixed with formalin and incubated with anti-E-selectin antibody for $1 \mathrm{~h}$. Secondary antibody was added and the plate was incubated for $1 \mathrm{~h}$. The substrate used was p-nitrophenylphosphate in diethanolamine. Optical densities were measured at $405 \mathrm{~nm}$ every $15 \mathrm{~min}$ for $1 \mathrm{~h}$.

\section{Statistical analysis}

Statistical comparisons were made with SPSS 17.0 (SPSS, Inc. Headquarters, Chicago, IL, USA) by ANOVA. For post hoc analysis Dunnet's test was used. When indicated, a nonparametric test, related-samples Wilcoxon signed-ranks test, was used. A $P$ value $<0.05$ was considered statistically significant. Data are presented as mean \pm S.E.M. or as median and the interquartile range (25th and 75th percentiles).

\section{Results}

\section{Gene expression}

The gene expression of IGF1R and IR was measured in HMVEC-Cs (Fig. 1A) and HUVECs (Fig. 1B). Results were calculated as the ratio of IGF1R to IR gene expression where IR expression was converted to one. The results are given as median and the interquartile range (25th and 75th percentiles). In HMVEC-Cs the IGF1R was $120 \cdot 3$ (112.6-173.6) times more abundant than the IR, and in HUVECs the IGF1R was $19.9(14 \cdot 7-22 \cdot 3)$ times more 

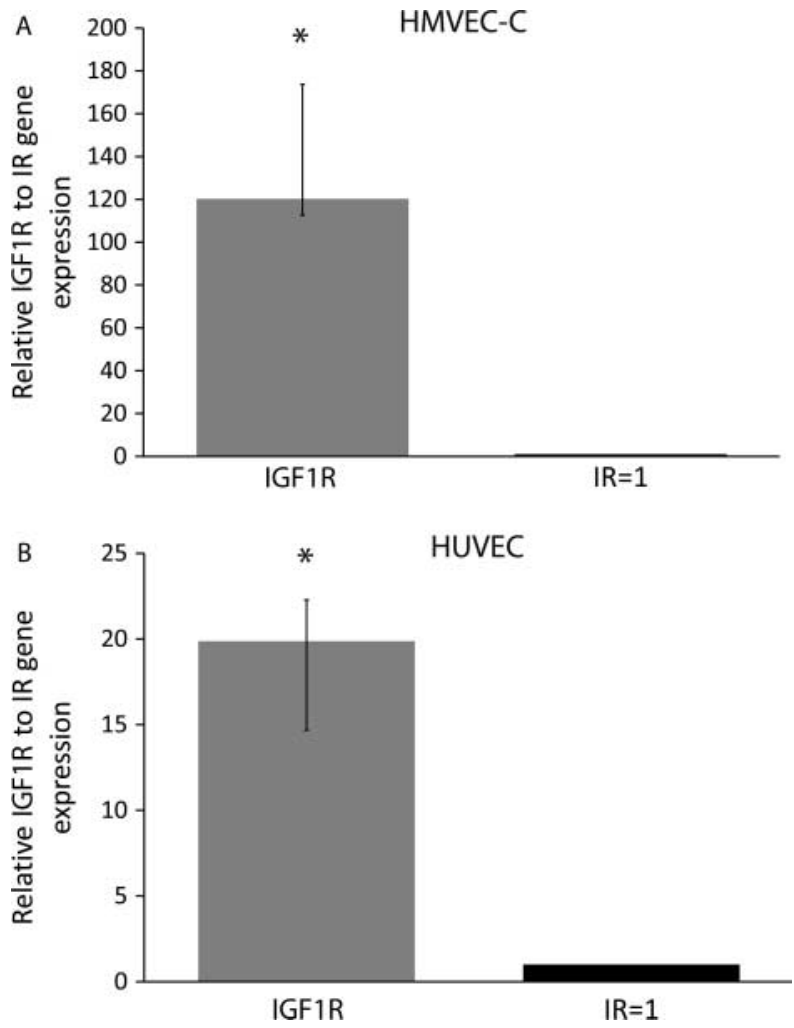

Figure 1 Gene expression of IR and IGF1R in HMVEC-Cs and HUVECs. Relative gene expression of IGF1R to IR in (A) HMVEC-Cs $(n=5)$ and (B) HUVECs $(n=10)$. IR is converted to 1 , data are fold expressions of IGF1R relative to IR, shown as median and the interquartile range (25th and 75 th percentiles). $* P<0.05$ when results were compared with related-samples Wilcoxon signed-ranks test.

abundant. The IGF1R/IR ratio was significantly higher in HMVEC-Cs than in HUVECs $(P<0 \cdot 05)$.

The median Ct values in HMVEC-Cs were 24.9 for IGF1R expression, 31.9 for IR expression and $15 \cdot 2$ for GAPDH expression. In HUVECs the median $\mathrm{Ct}$ values were $26 \cdot 8$ for IGF1R expression, $30 \cdot 5$ for IR expression and $21 \cdot 4$ for GAPDH expression.

We measured the gene expression of IGF1Rs and IRs in freshly isolated or cultured HUVECs to see if our culturing conditions altered receptor expression. No differences were found in the ratio of IGF1R to IR gene expression between cultured $(19 \cdot 9(14 \cdot 7-22 \cdot 3))$ and freshly isolated $(21.4(16 \cdot 9-25 \cdot 6))$ cells. There was no expression of GLUT4 in HUVECs or HMVEC-Cs (data not shown).

\section{$I R$ and IGF1R protein expression}

In HMVEC-Cs we detected IR and IGF1R protein by western blot (Fig. 2). When immunoprecipitating lysates with anti-IGF1R antibody and immunoblotting with anti-IR antibody, we discovered bands on the gel and vice versa, suggesting there were hybrid receptors present on these cells.
With ELISA we could quantify the amounts of IGF1R. In HMVEC-Cs we found $2 \cdot 77 \pm 0 \cdot 20 \mathrm{pg}$ IGF1R/ $\mu \mathrm{g}$ total protein. The same amounts were detected in HUVECs $(2 \cdot 86 \pm 0 \cdot 18 \mathrm{pg}$ IGF1R/ $\mu \mathrm{g}$ total protein). The IGF1R assay (detection range 250-16000 pg/l) was several times more sensitive than the IR assay (detection range 1250$80000 \mathrm{pg} / \mathrm{l})$, making it difficult to quantify IR in HMVEC-Cs or HUVECs as the levels in our study were below the detection range of the kit.

\section{Receptor phosphorylation with ELISA}

The amount of phosphorylated receptor protein on HMVEC-Cs (Fig. 3A) and HUVECs (Fig. 3B) was examined using phospho-specific ELISAs against IGF1R or IR. Cells were stimulated with insulin or IGF1 at $10^{-8} \mathrm{~mol} / 1$ and then lysed. Data were expressed as percent of unstimulated control. In HUVECs there was a significant difference between unstimulated control and IGF1 $10^{-8} \mathrm{~mol} / \mathrm{l}$ stimulated cells regarding IGF1R phosphorylation. In HMVEC-Cs IGF1 $10^{-8} \mathrm{~mol} / \mathrm{l}$ stimulated phosphorylation of both IGF1R and IR; insulin had no effect on receptor phosphorylation in either cell type.

\section{A IPIGF1R}

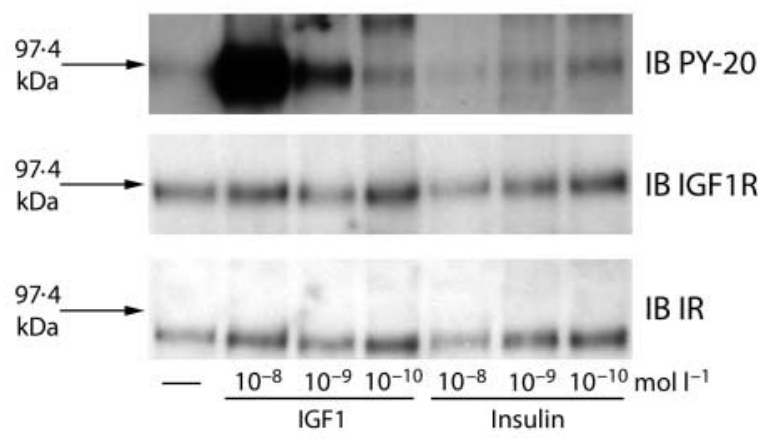

B IPIR

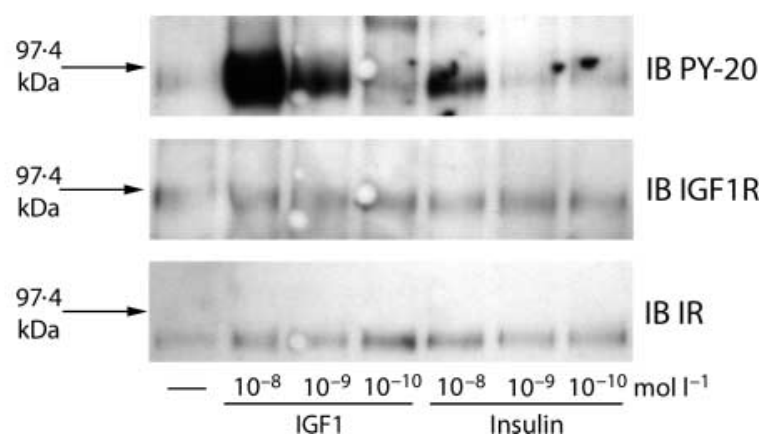

Figure 2 Abundance and phosphorylation of IGF1R and IR in HMVEC-Cs. Cell lysate was IP with polyclonal antibodies against either IGF1R $\beta$-subunit (C-20) (A) or the IR $\beta$-subunit (C-19) (B). Immunoblotting with a phosphotyrosine antibody (PY-20) was used to analyse phosphorylation. Results shown in the blots represent four different experiments. 


\section{A}
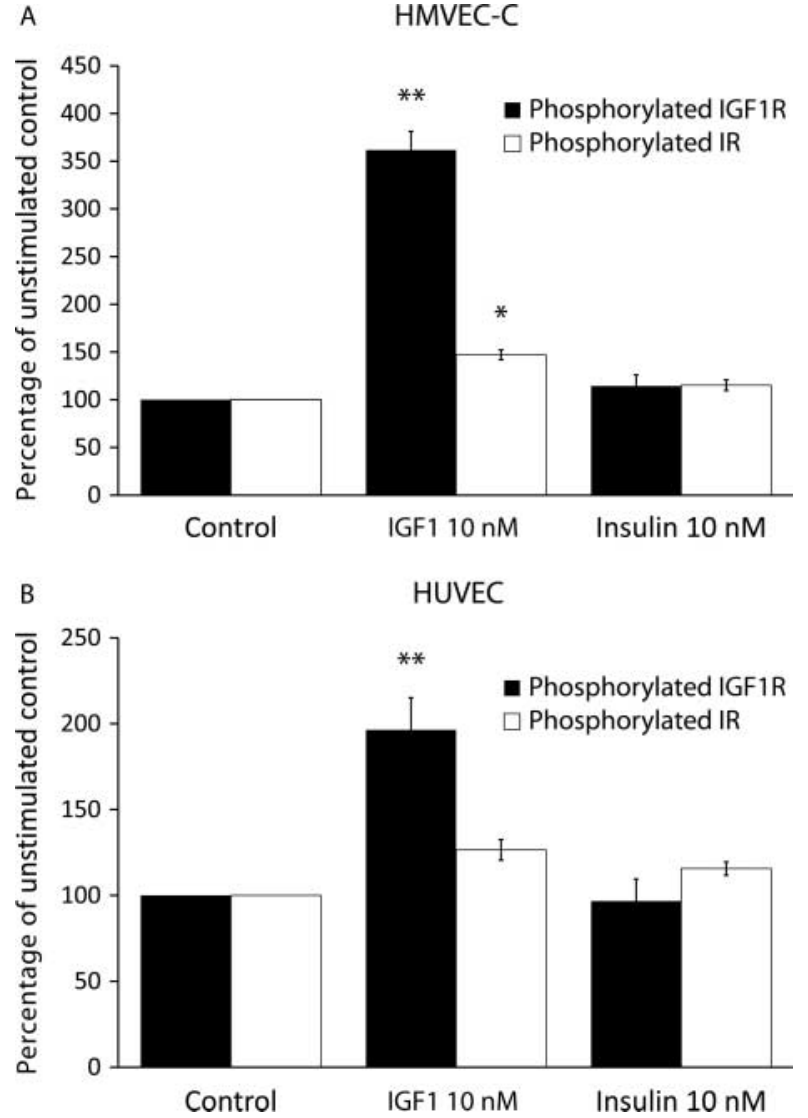

Figure 3 Phospho-ELISA in HMVEC-Cs and HUVECs. The amounts of phosphorylated IGF1R (black bars) or IR (white bars) were measured in (A) HMVEC-Cs or (B) HUVECs using ELISA. Results are mean \pm S.E.M. from five experiments. ${ }^{*} P<0 \cdot 05$ compared with unstimulated control. ${ }^{* *} P<0 \cdot 001$ compared with unstimulated control.

\section{Receptor phosphorylation with immunoblotting}

HMVEC-Cs were stimulated with insulin or IGF1 to investigate the phosphorylation of IR and IGF1R (Fig. 2). Cell lysates were IP with antibodies against the $\beta$-subunit of the IGF1R or the $\beta$-subunit of the IR. When IP with antiIGF1R we could detect phosphorylation stimulated by IGF1 $10^{-8} \mathrm{~mol} / 1$ and inconsistently by $10^{-9} \mathrm{~mol} / \mathrm{l}$. After IP with anti-IR we found phosphorylation stimulated by IGF1 $10^{-8} \mathrm{~mol} / \mathrm{l}$ and insulin $10^{-8} \mathrm{~mol} / \mathrm{l}$, and inconsistently by IGF1 $10^{-9} \mathrm{~mol} / \mathrm{l}$ and insulin $10^{-9} \mathrm{~mol} / \mathrm{l}$.

\section{DNA synthesis and glucose accumulation}

The effect of IGF1 on thymidine incorporation in HMVEC-Cs appeared at an IGF1 concentration of $10^{-9} \mathrm{~mol} / \mathrm{l}$ (Fig. 4) and was highly significant at IGF1 $10^{-8} \mathrm{~mol} / 1(P=0 \cdot 008)$. Insulin also tended to have an effect, appearing at a concentration of $10^{-8} \mathrm{~mol} / \mathrm{l}$, but this did not reach statistical significance.

As shown in Fig. 5, the effect of IGF1 on glucose accumulation was more pronounced and tended to appear at lower concentrations than with insulin. The effect of IGF1 on glucose accumulation was statistically significant at $10^{-7} \mathrm{~mol} / \mathrm{l} \quad(P=0 \cdot 018)$. VEGF also stimulated glucose accumulation $(P=0 \cdot 003)$.

\section{E-selectin expression}

No significant effects of insulin $10^{-8} \mathrm{~mol} / \mathrm{l}$ or IGF1 $10^{-8} \mathrm{~mol} / \mathrm{l}$ on E-selectin expression were found in HMVEC-Cs and HUVECs (Fig. 6A and B). Stimulation with TNF- $\alpha 5 \mathrm{ng} / \mathrm{ml}$ resulted in a significant increase in E-selectin expression compared with unstimulated control $(P<0 \cdot 001$ for both HMVEC-Cs and HUVECs).

The possible suppressant effect of insulin or IGF1 on E-selectin expression was further investigated by stimulating HMVEC-Cs with TNF- $\alpha(10,100,1000$ or $10000 \mathrm{pg} / \mathrm{ml})$ alone or with TNF- $\alpha(10,100,1000$ or $10000 \mathrm{pg} / \mathrm{ml})$ and insulin $10^{-8} \mathrm{~mol} / \mathrm{l}$ or TNF $\alpha$ and IGF1 $10^{-8} \mathrm{~mol} / \mathrm{l}$ (Fig. 7). We found no significant suppression of E-selectin by insulin or IGF1.

\section{Discussion}

To our knowledge this is the first study on IRs and IGF1Rs in HMVEC-Cs. We were able to demonstrate gene and protein expression of both receptors and also evidence of insulin/IGF1 hybrid receptors (Moxham et al. 1989). Quantification of receptor phosphorylation, which was possible using a new ELISA, showed activation of IGF1R and of insulin/IGF1 hybrid receptors by IGF1, whereas insulin had little effect even on its cognate receptors. This finding supports our DNA synthesis and glucose metabolism data, again indicating that HMVEC-Cs are sensitive to IGF1 while being insulin resistant.

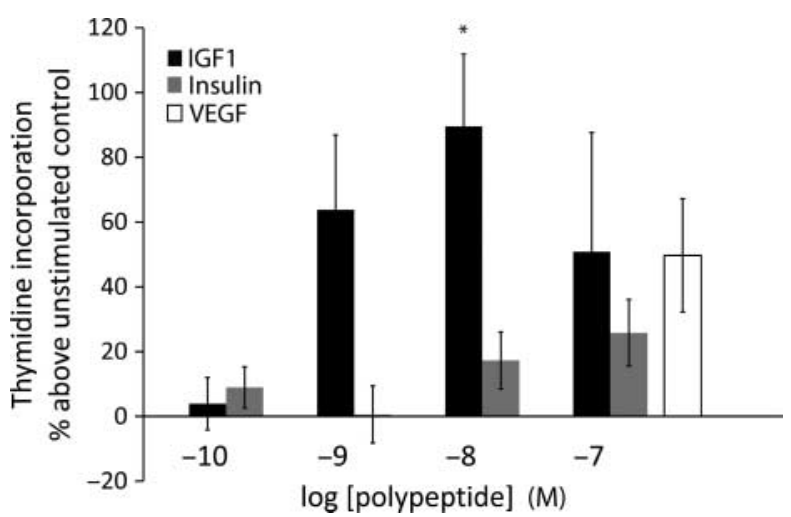

Figure 4 Thymidine incorporation in HMVEC-Cs. Effects of IGF1 (black bars), insulin (grey bars) and VEGF (white bar) on the incorporation of $\left[6-{ }^{3} \mathrm{H}\right]$ thymidine in HMVEC-Cs. Near confluent cells were stimulated with peptides in serum-free DMEM overnight and then incubated with $\left[6-{ }^{3} \mathrm{H}\right]$ thymidine for $3 \mathrm{~h}$. Results are mean \pm s.E.M. from four separate experiments. ${ }^{*} P<0 \cdot 05$ compared with unstimulated control. 


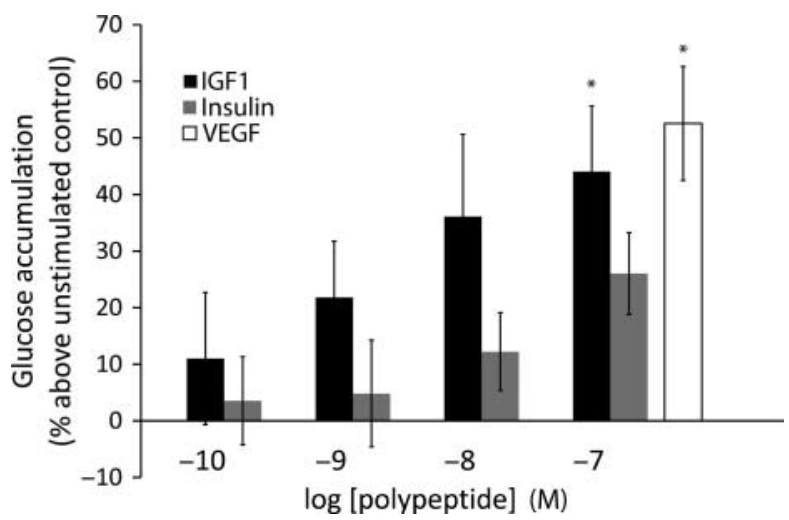

Figure 5 Glucose accumulation in HMVEC-Cs. Effects of IGF1 (black bars), insulin (grey bars) and VEGF (white bar) on the accumulation of D-[U- ${ }^{14}$ C]glucose in HMVEC-Cs. Near confluent cells were stimulated with peptides and $D-\left[U-{ }^{14} \mathrm{C}\right]$ glucose in serumfree DMEM for $3 \mathrm{~h}$. Results are mean \pm S.E.M. from five separate experiments. ${ }^{*} P<0 \cdot 05$ compared with unstimulated control.

Characterisation of cells by quantitative RT-PCR demonstrated that HMVEC-Cs expressed considerably more IGF1R mRNA than IR mRNA. We have previously described this in dermal microvascular cells and in macrovascular endothelial cells (Chisalita \& Arnqvist 2004, Nitert et al. 2005, Chisalita et al. 2006). IGF1R protein could be quantitatively measured by ELISA while IR was below the limit of detection. As the ELISA assay was fivefold less sensitive for IR than for IGF1R, we are cautious in drawing conclusions from these results. If a more sensitive IR ELISA was available we would probably be able to quantify IR too. Ligand binding, a classical method for analysing receptor numbers, has shown less specific binding of insulin than IGF1 to micro- and macrovascular cells (Chisalita \& Arnqvist 2004, Nitert et al. 2005, Chisalita et al. 2006). The evidence available thus suggests that IGF1Rs are more abundant than IRs in HMVEC-Cs. We compared freshly isolated and cultured HUVECs and could find no difference in the gene expression of IGF1R relative to IR. This suggests that the use of cultured cells is a suitable model for studying the effects of insulin or IGF1 on vascular cells.

When immunoprecipitating our samples with antibodies specific for the IGF1R $\beta$-subunit we could detect both the IGF1R $\beta$-subunit and the IR $\beta$-subunit on the gel, and after IP with antibodies specific for the IR $\beta$-subunit we could detect both the IR $\beta$-subunit and the IGF1R $\beta$-subunit. This can be explained by the assembly of the IR and IGF1R $\alpha \beta$-dimers resulting in the formation of an insulin/IGF1 hybrid receptor with one $\alpha \beta$-dimer from each receptor (Moxham et al. 1989). Hybrid receptors have been shown to have a binding affinity similar to that of the IGF1R, i.e. binding IGF1, but not insulin, with high affinity (Soos et al. 1993, Slaaby et al. 2006).

As insulin and IGF1 can cross react with each other's receptors (Siddle et al. 2001, Werner et al. 2008), we studied specific receptor phosphorylation to see which receptors were activated by IGF1 and insulin. Receptor phosphorylation was measured using conventional western blot after IP and also with phospho-specific ELISAs, making it possible to quantitate receptor phosphorylation. As expected the IGF1R was stimulated by IGF1 but not by insulin at concentrations $\leq 10^{-8} \mathrm{~mol} / \mathrm{l}$. A paradoxical observation was that the IR was significantly stimulated by IGF1 but not by insulin when using phospho-ELISA. As the IR was also found to be phosphorylated by IGF1 using western blot, we interpret this observation as an effect of insulin/IGF1 hybrid receptors where IGF1 binding to the IGF1R $\alpha \beta$-dimer transphosphorylates the IR $\beta$-subunit (Ward et al. 2007). This corroborates with the findings of Abbas et al. (2011) who showed that reduction in the expression of IGF1R by siRNA, thus reducing the number of insulin/IGF1 hybrid receptors, increased the response to insulin in HUVECs.

The effects of both insulin and IGF1 on glucose accumulation in HMVEC-Cs were enhanced at increasing concentrations, with the effect of IGF1 being more pronounced than that of insulin. This finding indicates that HMVEC-Cs, like dermal microvascular cells, are more sensitive to IGF1 than to insulin (Chisalita \& Arnqvist
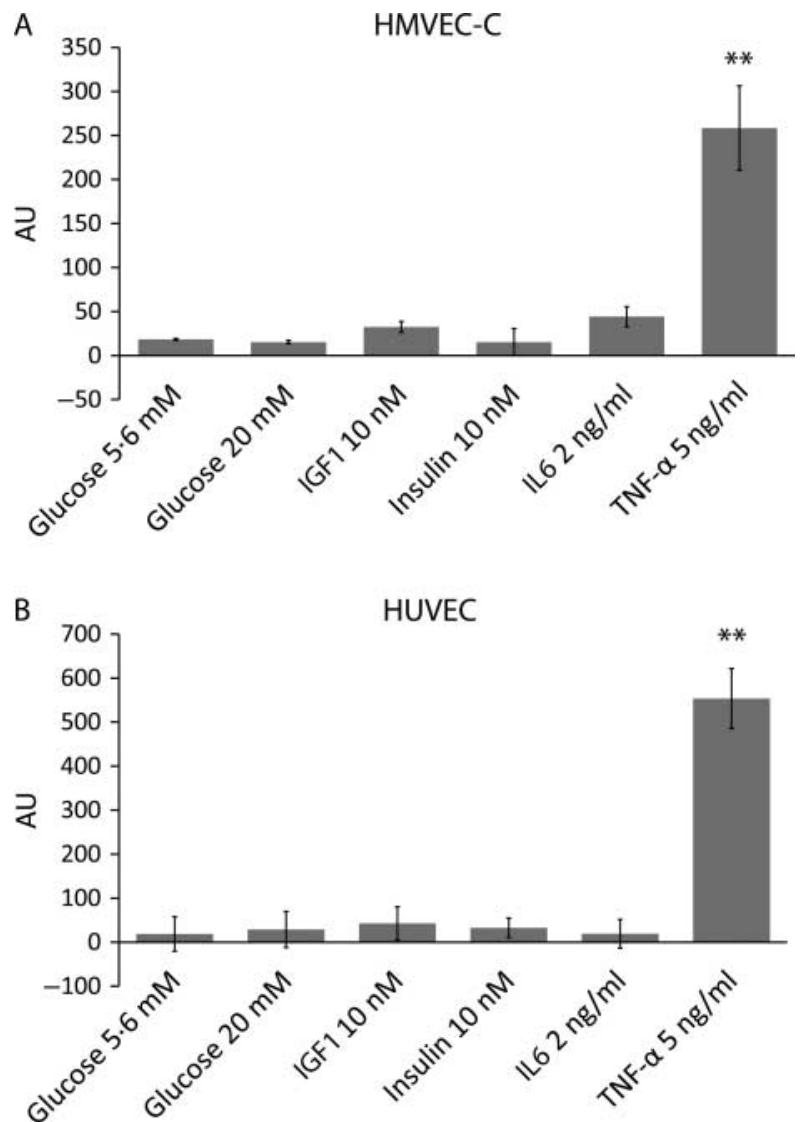

Figure 6 E-selectin expression in HMVEC-Cs and HUVECs. The expression of E-selectin was measured in (A) HMVEC-Cs $(n=5)$ or (B) HUVECs $(n=4)$ after $4 \mathrm{~h}$ stimulation with different conditions. $* * P<0 \cdot 001$ compared with glucose $5 \cdot 6 \mathrm{mM}$. 


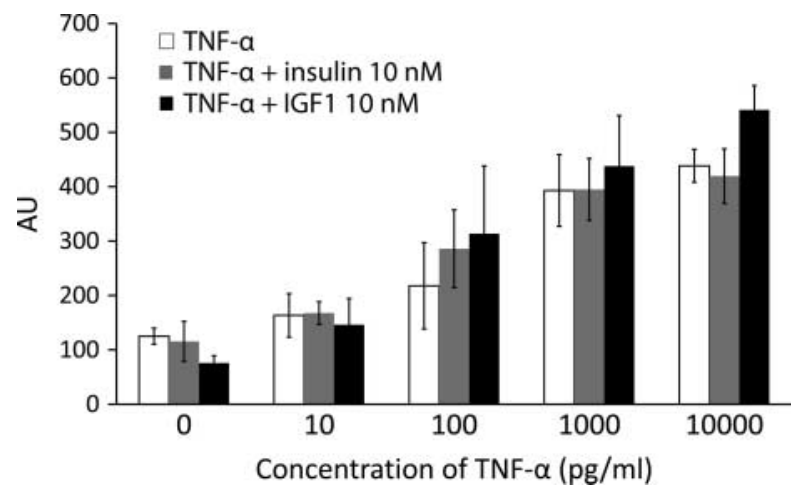

Figure 7 Effects of insulin and IGF1 on TNF- $\alpha$-induced E-selectin expression in HMVEC-Cs. E-selectin expression was measured after stimulation with TNF- $\alpha$ alone (white bars), TNF- $\alpha$ and insulin $10^{-8} \mathrm{~mol} / \mathrm{l}$ (grey bars) or TNF- $\alpha$ and IGF1 $10^{-8} \mathrm{~mol} / \mathrm{l}$ (black bars). Results are mean \pm S.E.M. from three separate experiments.

2004). It should be noted that the insulin-sensitive glucose transporter, GLUT4, which accounts for glucose uptake in skeletal muscle and fat (Leto \& Saltiel 2012), was not expressed in these cells. In support of our glucose metabolism data, the cells were more responsive to IGF1 with regards to mitogenic effects. The common concept is that insulin stimulates metabolism and IGF1 growth (Dupont \& LeRoith 2001, Siddle et al. 2001). Our data from phospho-ELISAs, as discussed above, indicate that receptor activation of IGF1R and hybrid receptors only occurred with IGF1 and that insulin had no significant effect even on its cognate receptor. This could explain why we observed no significant effects of insulin while IGF1 had both metabolic and mitogenic effects. In humans the concentration of free circulating bioactive IGF1 is $10^{-10}$ to $10^{-9} \mathrm{~mol} / \mathrm{l}$ while the highest postprandial insulin concentrations reached are around $10^{-9} \mathrm{~mol} / \mathrm{l}$ (Carey et al. 2003, Frystyk 2004). In diabetes, particularly in type 1 diabetes, circulating IGF1 bioactivity is low, probably due to insulin deficiency in the portal vein (Bereket et al. 1999). One may speculate that this may be of special importance for IGF-sensitive cells as HMVEC-Cs leading, amongst other things, to impaired NO production (Tsukahara et al. 1994).

The role of inflammation in vascular disease has been in focus in recent years. We found that TNF- $\alpha$ had a pronounced pro-inflammatory effect in HMVEC-Cs and also in HUVECs, whereas high glucose, insulin, IGF1 or IL6 did not affect E-selectin expression. Prominent effects of TNF- $\alpha$ on E-selectin expression have previously been shown in HUVECs and in human aortic endothelial cells (Strindhall et al. 1997, Ewart et al. 2008, Mako et al. 2010). The lack of insulin or IGF1 effects is in agreement with observations made with HUVECs (Balaram et al. 1997, Montagnani et al. 2002, Madonna et al. 2004). High glucose concentrations (20 $\mathrm{mmol} / 1$ or higher) was found to increase E-selectin expression in HUVECs after incubation for $24 \mathrm{~h}$ or longer (Zheng et al. 2008, Wang et al. 2010). We incubated our cells in high concentration glucose for $4 \mathrm{~h}$, which could explain the absence of a glucose effect. In future studies it is therefore of interest to study the effect of high glucose concentration on E-selectin expression in HMVEC-Cs under prolonged incubation; this is especially interesting as hyperglycaemia in diabetes seems to be particularly harmful for the microcirculation (UKPDS 1998). Stimulation of HMVEC-Cs with TNF- $\alpha$ showed a dose-related E-selectin expression similar to previous results with HUVECs (Mako et al. 2010). The lack of anti-inflammatory effects of insulin and IGF1 might be explained by the more potent pro-inflammatory effects of TNF- $\alpha$.

In conclusion, we show that HMVEC-Cs express more IGF1Rs than IRs and at physiological concentrations of insulin and IGF1, HMVEC-Cs mainly react to IGF1 probably due to the predominance of IGF1Rs and insulin/IGF1 hybrid receptors. TNF- $\alpha$ has a pronounced pro-inflammatory effect on HMVEC-Cs, which is not counteracted by insulin or IGF1.

\section{Declaration of interest}

The authors declare that there is no conflict of interests that should be perceived as prejudicing the impartiality of the research reported.

\section{Funding}

Financial support was obtained from the County Council of Östergötland, the Barndiabetesfonden and the Lions foundation.

\section{Acknowledgements}

The authors thank Anna-Kristina Granath for excellent technical assistance.

\section{References}

Abbas A, Imrie H, Viswambharan H, Sukumar P, Rajwani A, Cubbon RM, Gage M, Smith J, Galloway S, Yuldeshava N et al. 2011 The insulin-like growth factor-1 receptor is a negative regulator of nitric oxide bioavailability and insulin sensitivity in the endothelium. Diabetes $\mathbf{6 0}$ 2169-2178. (doi:10.2337/db11-0197)

Asghar O, Al-Sunni A, Khavandi K, Khavandi A, Withers S, Greenstein A, Heagerty AM \& Malik RA 2009 Diabetic cardiomyopathy. Clinical Science 116 741-760. (doi:10.1042/CS20080500)

Bäck K \& Arnqvist HJ 2009 Changes in insulin and IGF-I receptor expression during differentiation of human preadipocytes. Growth Hormone \& IGF Research 19 101-111. (doi:10.1016/j.ghir.2008.06.004)

Balaram SK, Agrawal DK, Allen RT, Kuszynski CA \& Edwards JD 1997 Cell adhesion molecules and insulin-like growth factor-1 in vascular disease. Journal of Vascular Surgery 25 866-876. (doi:10.1016/S07415214(97)70216-7)

Bereket A, Lang CH \& Wilson TA 1999 Alterations in the growth hormoneinsulin-like growth factor axis in insulin dependent diabetes mellitus. Hormone and Metabolic Research 31 172-181. (doi:10.1055/s-2007-978716) Carey PE, Halliday J, Snaar JE, Morris PG \& Taylor R 2003 Direct assessment of muscle glycogen storage after mixed meals in normal and type 2 diabetic subjects. American Journal of Physiology. Endocrinology and Metabolism 284 E688-E694. 
Chisalita SI \& Arnqvist HJ 2004 Insulin-like growth factor I receptors are more abundant than insulin receptors in human micro- and macrovascular endothelial cells. American Journal of Physiology. Endocrinology and Metabolism 286 E896-E901. (doi:10.1152/ajpendo.00327.2003)

Chisalita SI, Nitert MD \& Arnqvist HJ 2006 Characterisation of receptors for IGF-I and insulin; evidence for hybrid insulin/IGF-I receptor in human coronary artery endothelial cells. Growth Hormone \& IGF Research 16 258-266. (doi:10.1016/j.ghir.2006.06.003)

Cines DB, Pollak ES, Buck CA, Loscalzo J, Zimmerman GA, McEver RP, Pober JS, Wick TM, Konkle BA, Schwartz BS et al. 1998 Endothelial cells in physiology and in the pathophysiology of vascular disorders. Blood 91 3527-3561.

Dandona P, Chaudhuri A, Ghanim H \& Mohanty P 2009 Insulin as an antiinflammatory and antiatherogenic modulator. Journal of the American College of Cardiology 53 S14-S20. (doi:10.1016/j.jacc.2008.10.038)

Delafontaine P, Song YH \& Li Y 2004 Expression, regulation, and function of IGF-1, IGF-1R, and IGF-1 binding proteins in blood vessels. Arteriosclerosis, Thrombosis, and Vascular Biology 24 435-444. (doi:10.1161/01.ATV. 0000105902.89459.09)

Dupont J \& LeRoith D 2001 Insulin and insulin-like growth factor I receptors: similarities and differences in signal transduction. Hormone Research 55 (Suppl 2) 22-26. (doi:10.1159/000063469)

Ewart MA, Kohlhaas CF \& Salt IP 2008 Inhibition of tumor necrosis factor $\alpha$-stimulated monocyte adhesion to human aortic endothelial cells by AMP-activated protein kinase. Arteriosclerosis, Thrombosis, and Vascular Biology 28 2255-2257. (doi:10.1161/ATVBAHA.108.175919)

Frystyk J 2004 Free insulin-like growth factors - measurements and relationships to growth hormone secretion and glucose homeostasis. Growth Hormone \& IGF Research 14 337-375. (doi:10.1016/j.ghir.2004.06.001)

Hedman CA, Frystyk J, Lindstrom T, Chen JW, Flyvbjerg A, Orskov H \& Arnqvist HJ 2004 Residual $\beta$-cell function more than glycemic control determines abnormalities of the insulin-like growth factor system in type 1 diabetes. Journal of Clinical Endocrinology and Metabolism 89 6305-6309. (doi:10.1210/jc.2004-0572)

Johansson GS, Chisalita SI \& Arnqvist HJ 2008 Human microvascular endothelial cells are sensitive to IGF-I but resistant to insulin at the receptor level. Molecular and Cellular Endocrinology 296 58-63. (doi:10.1016/j.mce. 2008.07.012)

Kim JA, Montagnani M, Koh KK \& Quon MJ 2006 Reciprocal relationships between insulin resistance and endothelial dysfunction: molecular and pathophysiological mechanisms. Circulation 113 1888-1904. (doi:10.1161/ CIRCULATIONAHA.105.563213)

Leto D \& Saltiel AR 2012 Regulation of glucose transport by insulin: traffic control of GLUT4. Nature Reviews. Molecular Cell Biology 13 383-396. (doi:10.1038/nrm3351)

Madonna R, Pandolfi A, Massaro M, Consoli A \& De Caterina R 2004 Insulin enhances vascular cell adhesion molecule-1 expression in human cultured endothelial cells through a pro-atherogenic pathway mediated by p38 mitogen-activated protein-kinase. Diabetologia 47 532-536. (doi:10.1007/s00125-004-1330-x)

Mako V, Czucz J, Weiszhar Z, Herczenik E, Matko J, Prohaszka Z \& Cervenak L 2010 Proinflammatory activation pattern of human umbilical vein endothelial cells induced by IL-1 $\beta$, TNF- $\alpha$, and LPS. Cytometry. Part $A$ 77 962-970. (doi:10.1002/cyto.a.20952)

Montagnani M, Golovchenko I, Kim I, Koh GY, Goalstone ML, Mundhekar AN, Johansen M, Kucik DF, Quon MJ \& Draznin B 2002 Inhibition of phosphatidylinositol 3-kinase enhances mitogenic actions of insulin in endothelial cells. Journal of Biological Chemistry 277 1794-1799. (doi:10.1074/ jbc.M103728200)

Moxham CP, Duronio V \& Jacobs S 1989 Insulin-like growth factor I receptor $\beta$-subunit heterogeneity. Evidence for hybrid tetramers composed of insulin-like growth factor I and insulin receptor heterodimers. Journal of Biological Chemistry 264 13238-13244.
Nitert MD, Chisalita SI, Olsson K, Bornfeldt KE \& Arnqvist HJ 2005 IGF-I/insulin hybrid receptors in human endothelial cells. Molecular and Cellular Endocrinology 229 31-37. (doi:10.1016/j.mce.2004.10.003)

Pambianco G, Costacou T, Ellis D, Becker DJ, Klein R \& Orchard TJ 2006 The 30-year natural history of type 1 diabetes complications: the Pittsburgh Epidemiology of Diabetes Complications Study experience. Diabetes $\mathbf{5 5}$ 1463-1469. (doi:10.2337/db05-1423)

Picchi A, Capobianco S, Qiu T, Focardi M, Zou X, Cao JM \& Zhang C 2010 Coronary microvascular dysfunction in diabetes mellitus: a review. World Journal of Cardiology 2 377-390. (doi:10.4330/wjc.v2.111.377)

Siddle K, Urso B, Niesler CA, Cope DL, Molina L, Surinya KH \& Soos MA 2001 Specificity in ligand binding and intracellular signalling by insulin and insulin-like growth factor receptors. Biochemical Society Transactions 29 513-525. (doi:10.1042/BST0290513)

Slaaby R, Schaffer L, Lautrup-Larsen I, Andersen AS, Shaw AC, Mathiasen IS \& Brandt J 2006 Hybrid receptors formed by insulin receptor (IR) and insulin-like growth factor I receptor (IGF-IR) have low insulin and high IGF-1 affinity irrespective of the IR splice variant. Journal of Biological Chemistry 281 25869-25874. (doi:10.1074/jbc.M605189200)

Soos MA, Field CE \& Siddle K 1993 Purified hybrid insulin/insulin-like growth factor-I receptors bind insulin-like growth factor-I, but not insulin, with high affinity. Biochemical Journal 290 419-426.

Strindhall J, Lundblad A \& Pahlsson P 1997 Interferon- $\gamma$ enhancement of E-selectin expression on endothelial cells is inhibited by monensin. Scandinavian Journal of Immunology 46 338-343. (doi:10.1046/j.1365-3083. 1997.d01-135.x)

Tarquini R, Lazzeri C, Pala L, Rotella CM \& Gensini GF 2010 The diabetic cardiomyopathy. Acta Diabetologica 48 173-181. (doi:10.1007/ s00592-010-0180-x)

Tsukahara H, Gordienko DV, Tonshoff B, Gelato MC \& Goligorsky MS 1994 Direct demonstration of insulin-like growth factor-I-induced nitric oxide production by endothelial cells. Kidney International 45 598-604. (doi:10.1038/ki.1994.78)

UK Prospective Diabetes Study (UKPDS) Group 1998 Intensive bloodglucose control with sulphonylureas or insulin compared with conventional treatment and risk of complications in patients with type 2 diabetes (UDPDS 33). Lancet 352 837-853. (doi:10.1016/S0140-6736(98)07019-6)

Wang GF, Wu SY, Xu W, Jin H, Zhu ZG, Li ZH, Tian YX, Zhang JJ, Rao JJ \& Wu SG 2010 Geniposide inhibits high glucose-induced cell adhesion through the NF-kappaB signaling pathway in human umbilical vein endothelial cells. Acta Pharmacologica Sinica 31 953-962. (doi:10.1038/aps. 2010.83)

Ward CW, Lawrence MC, Streltsov VA, Adams TE \& McKern NM 2007 The insulin and EGF receptor structures: new insights into ligand-induced receptor activation. Trends in Biochemical Sciences 32 129-137. (doi:10.1016/ j.tibs.2007.01.001)

Werner H, Weinstein D \& Bentov I 2008 Similarities and differences between insulin and IGF-I: structures, receptors, and signalling pathways. Archives of Physiology and Biochemistry 114 17-22. (doi:10.1080/13813450801900694)

Zheng HT, Zhou LN, Huang CJ, Hua X, Jian R, Su BH \& Fang F 2008 Selenium inhibits high glucose- and high insulin-induced adhesion molecule expression in vascular endothelial cells. Archives of Medical Research 39 373-379. (doi:10.1016/j.arcmed.2007.12.007)

Received in final form 20 June 2012

Accepted 23 July 2012

Made available online as an Accepted Preprint 23 July 2012 